\title{
Dealing with an Unconventional Genetic Code in Mitochondria: The Biogenesis and Pathogenic Defects of the 5-Formylcytosine Modification in Mitochondrial tRNA ${ }^{\text {Met }}$
}

\author{
Lindsey Van Haute *, Christopher A. Powell and Michal Minczuk* \\ Mitochondrial Genetics, Medical Research Council Mitochondrial Biology Unit, University of Cambridge, \\ Wellcome Trust/MRC Building, Cambridge Biomedical Campus, Hills Road, Cambridge CB2 0XY, UK; \\ cap71@mrc-mbu.cam.ac.uk \\ * Correspondence: lindsey.van.haute@mrc-mbu.cam.ac.uk (L.V.H.); \\ michal.minczuk@mrc-mbu.cam.ac.uk (M.M.) \\ Academic Editor: Valérie de Crécy-Lagard \\ Received: 13 January 2017; Accepted: 24 February 2017; Published: 2 March 2017
}

\begin{abstract}
Human mitochondria contain their own genome, which uses an unconventional genetic code. In addition to the standard AUG methionine codon, the single mitochondrial tRNA Methionine (mt-tRNA ${ }^{\text {Met}}$ ) also recognises AUA during translation initiation and elongation. Post-transcriptional modifications of $\mathrm{tRNAs}$ are important for structure, stability, correct folding and aminoacylation as well as decoding. The unique 5-formylcytosine $\left(f^{5} \mathrm{C}\right)$ modification of position 34 in mt-tRNA Met has been long postulated to be crucial for decoding of unconventional methionine codons and efficient mitochondrial translation. However, the enzymes responsible for the formation of mitochondrial $\mathrm{f}^{5} \mathrm{C}$ have been identified only recently. The first step of the $\mathrm{f}^{5} \mathrm{C}$ pathway consists of methylation of cytosine by NSUN3. This is followed by further oxidation by ABH1. Here, we review the role of $\mathrm{f}^{5} \mathrm{C}$, the latest breakthroughs in our understanding of the biogenesis of this unique mitochondrial tRNA modification and its involvement in human disease.
\end{abstract}

Keywords: mitochondria; tRNA; NSUN3; 5-methylcytosine; 5-formylcytosine; RNA modification; translation

\section{Introduction}

Mitochondria have their own DNA (mtDNA) that encodes thirteen essential subunits of the oxidative phosphorylation (OXPHOS) system. Apart from these genes, the human mitochondrial transcriptome also consists of two ribosomal RNAs (mt-rRNA) and a full set of 22 transfer RNAs (mt-tRNA). All other proteins necessary for the expression of mtDNA, including those responsible for post-transcriptional RNA modifications, are encoded by nuclear genes (nDNA) and imported into mitochondria upon translation in the cytosol. Perturbation of mitochondrial gene expression can lead mitochondrial diseases. The pathological defects of mitochondrial gene expression can result from mutations either in mtDNA or nDNA. For a broad overview of processes and proteins involved in mitochondrial gene expression and their role in human pathology, we refer to recent reviews [1-7].

The translation of a messenger RNA (mRNA) into its corresponding polypeptide chain is dependent on the precise interactions between the three bases of the mRNA's triplet codon and the triplet anticodon of the cognate tRNA. In mammalian mitochondria, all mt-tRNAs have to recognize at least two different codons. For any given mt-tRNA, the recognized codons always share the same base identity at the first and second positions, but differ at the third. Consequently, position 34 (the first position of the anticodon, the "wobble base") in the mt-tRNA cannot always base pair with the 
third nucleotide of the codon according to the conventional Watson-Crick pairing rules. There are eight mt-tRNAs that recognize four codons each. In all these cases, position 34 of the mt-tRNA, the wobble base, is occupied by uridine, which is capable of base pairing with any of the four bases due to enhanced conformational flexibility within the anticodon loop [8]. However, the remaining fourteen tRNAs interact with a purine or a pyrimidine in the third codon position and consequently recognize exactly two codons. This increase in discrimination by the wobble base is achieved through post-transcriptional modifications.

The mammalian mitochondrial genetic code differs from the universal genetic code by using unconventional codons [9]. UGA encodes tryptophan. AGA and AGG (AGR), which encode arginine in the universal code, are not used by mitochondrial open reading frames (ORFs) during translation elongation and have been for years recognized as 'stop' signals. However, the use of the AGR codons as stop signal has been questioned by the observation of a -1 frameshift by the mitoribosome, which places a standard UAG stop codon at the A-site [10], and is still the matter of lively debate [11-13]. Finally, in addition to conventional AUG, methionine coding is expanded to AUA (as well as AUU, but only as an initiation codon), with all these codons being recognized by a single tRNA Methionine (tRNA $^{\text {Met }}$ ) bearing a CAU anticodon, serving as both the elongator and initiator tRNA [14].

As with all known tRNAs, mt-tRNAs undergo numerous post-transcriptional nucleotide modifications and a great range of chemical diversity exists with bases undergoing methylations and formylations, along with several others [15,16]. Chemical nucleotide modifications are crucial for tRNA structure, stability, correct folding and aminoacylation. Additionally, modifications ensure the efficiency and stringent accuracy that is required during decoding in mitochondrial translation. Mitochondrial tRNA modifications are introduced by several site-specific enzymes encoded in the nucleus. For a detailed overview of known nuclear factors that are involved in post-transcriptional processing and modification of mt-tRNAs and their role in mitochondrial disease, we refer to other recently published work [15,17-27].

This review article focuses on the 5-formylcytosine $\left(f^{5} \mathrm{C}\right)$ modification of the wobble position of mt-tRNA ${ }^{\text {Met }}$, which allows for the recognition of unconventional mitochondrial methionine codons. We also describe the recent discovery of a sequential pathway and the enzymes involved in the generation of this post-transcriptional modification. We discuss the in vitro characterization of this modification and its possible role in vivo. Furthermore, we describe the role of mutations in mt-tRNA ${ }^{\text {Met }}$, their effect on $\mathrm{f}^{5} \mathrm{C}$ formation and the lack of $\mathrm{f}^{5} \mathrm{C}$ in a patient with mitochondrial disease.

\section{Discovery and Formation of 5-Formylcytosine at Position C34 of mt-tRNA Met $^{\text {mation }}$}

In 1994, a novel and unique modified nucleoside, $\mathrm{f}^{5} \mathrm{C}$, was found at the wobble position of bovine liver mitochondrial tRNA ${ }^{\text {Met }}$ [28] and the parasitic nematode Ascaris suum [29]. In the subsequent years, it was shown that mt-tRNA ${ }^{\text {Met }}$ from Loligo breekeri (squid) [30], Drosophila melanogaster (fruit fly) [31], Gallus domesticus (chicken), Xenopus laevis (frog) and Rattus norvegicus (rat) [32] also possess $\mathrm{f}^{5} \mathrm{C} 34$ and it was therefore considered universal in eukaryotic mt-tRNA ${ }^{\mathrm{Met}}$. However, the presence of this modification in human mt-tRNA ${ }^{\text {Met }}$ has only recently been confirmed $[33,34] . \mathrm{f}^{5} \mathrm{C}$ has not been detected in other mitochondrial RNAs.

Although $\mathrm{f}^{5} \mathrm{C} 34$ on $\mathrm{mt}$-tRNA ${ }^{\text {Met }}$ was identified almost three decades ago, the enzymes responsible for this modification have only very recently been discovered by three independent groups, almost simultaneously [33-35]. It was shown that initially a methyl group is added to the cytosine at position 34 of mt-tRNA ${ }^{\mathrm{Met}}$, which is then further converted to a formyl group. One of the key experiments to reveal the biosynthetic pathway of $\mathrm{f}^{5} \mathrm{C}$, was to identify the carbon source of the $\mathrm{C} 34$ formyl group of mt-tRNA ${ }^{\text {Met }}$. Many metabolites use formyl-tetrahydrofolate (formyl-THF) as the formyl donor. On the other hand, 5-formyldeoxycytidine $\left(\mathrm{f}^{5} \mathrm{dC}\right)$ found as a stable modification of DNA [36], is generated by oxidation of the 5-methyldeoxycytidine $\left(\mathrm{m}^{5} \mathrm{dC}\right)$ intermediate. In this case, the carbon from the methyl group donor, $S$-adenosyl methionine (SAM), is found in the $\mathrm{f}^{5} \mathrm{dC}$ formyl group. Metabolic isotope labelling with precursors of formyl-THF or SAM revealed that the carbon atom of the formyl group in 
mt-tRNA ${ }^{\text {Met }} \mathrm{f}^{5} \mathrm{C} 34$ was derived from SAM rather than formyl-THF. These results suggested stepwise biogenesis of $\mathrm{f}^{5} \mathrm{C} 34$ with an initial SAM-dependent methylation of $\mathrm{C} 34$, to form $\mathrm{m}^{5} \mathrm{C} 34$, followed by hydroxylation and oxidation of the methyl group (Figure 1), reminiscent of $\mathrm{m}^{5} \mathrm{dC}$ formation in DNA [33].

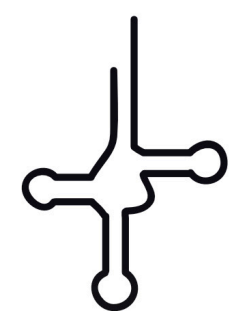

mt-tRNA ${ }^{\mathrm{Met}}(\mathrm{C} 34)$<smiles>[R19]n1ccc(N)nc1=O</smiles>

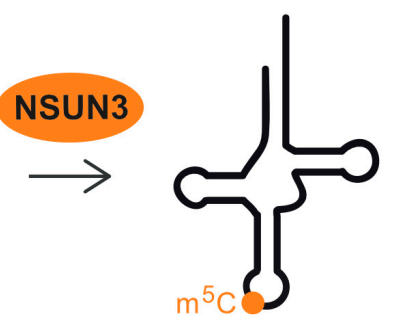

mt-tRNA ${ }^{\mathrm{Met}}\left(\mathrm{m}^{5} \mathrm{C} 34\right)$

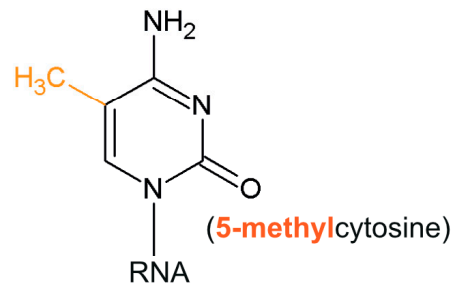

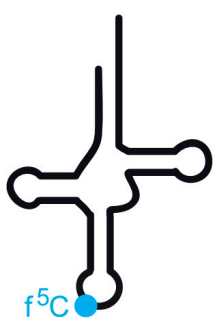

mt-tRNA ${ }^{\mathrm{Met}}\left(\mathrm{f}^{5} \mathrm{C} 34\right)$

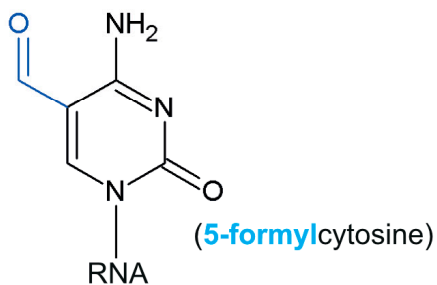

Figure 1. Graphical overview of the tRNA Methionine (mt-tRNA ${ }^{\text {Met }}$ ) formylation pathway. NSUN3 methylates unmodified $\mathrm{C} 34$ to form 5-methylcytosine $\left(\mathrm{m}^{5} \mathrm{C}\right)$ which is then further oxidized into 5-formylcytosine $\left(\mathrm{f}^{5} \mathrm{C}\right)$ by $\mathrm{ABH} 1$.

The methyltransferase NSUN3 has been identified as responsible for the first step of the process of $\mathrm{f}^{5} \mathrm{C}$ formation, namely, the methylation of carbon 5 to form methylcytosine $\left(\mathrm{m}^{5} \mathrm{C}\right)$. NSUN3 belongs to the family of NOL1/NOP2/Sun (NSUN) domain-containing proteins. Other members of this family of putative RNA methyltransferases have been shown to methylate cytosolic tRNA (NSUN2 and NSUN6) $[37,38]$, cytosolic rRNA (NSUN1/NOP2, NSUN5) $[39,40]$ or mitochondrial rRNA (NSUN4) [41,42].

A large-scale proteomic approach had previously suggested that NSUN3 localizes to the mitochondrial matrix [43]. Having confirmed the mitochondrial localization of the NSUN3 protein, a number of high-throughput techniques employed by different groups further identified mt-tRNA ${ }^{\text {Met }}$ as the target of NSUN3. Firstly, ultraviolet crosslinking and immunoprecipitation coupled with high-throughput sequencing (HITS-CLIP), identified mt-RNA ${ }^{\text {Met }}$ by irreversibly binding the protein to its target RNA [34,35]. Likewise, methylation-individual nucleotide resolution cross-linking and immunoprecipitation (miCLIP), which relies on the overexpression of a mutated protein that irreversibly binds to the methylation site, arrived at the same conclusion. The same is true for exposure to the cytidine derivative 5-Azacytidine (5-AzaC), which becomes incorporated into nascent RNA and specifically traps $\mathrm{m}^{5} \mathrm{C}$ RNA methyltransferases on their target in 5-azacytidine cross-linking and analysis of cDNA (5-AzaC CRAC) [35].

The above mentioned three studies which identified NSUN3 as the first step enzyme towards $\mathrm{f}^{5} \mathrm{C}$ formation have used different approaches to study the consequences of its inactivation, namely CRISPR-Cas9 generated knockout human embryonic kidney (HEK293T) cells [33], patient derived primary dermal fibroblasts that carry compound heterozygous predicted loss-of-function variants in NSUN3 [34] and small interfering RNA (siRNA) treated HeLa cells [35], and yet reached generally similar conclusions. The lack of NSUN3 in human cells results in the loss of $m^{5} \mathrm{C} 34$ and $\mathrm{f}^{5} \mathrm{C} 34$ of mt-tRNA ${ }^{\text {Met }}$. Furthermore, in vitro reconstitution experiments in combination with mass spectrometry also prove that NSUN3 is required for methylation of mt-tRNA ${ }^{\text {Met }}$ [33].

The enzyme responsible for the further conversion of 5-methylcytosine to 5-formylcytosine was identified as ABH1 (ALKBH1), a member of the AlkB-like $\mathrm{Fe}^{2+} / \alpha$-ketoglutarate-dependent 
dioxygenases [35]. Other members of this family have been shown to play a role in DNA repair by removal of alkyl adducts from nucleobases by oxidative dealkylation [44]. Depletion of ABH1 abolishes the formation of $\mathrm{f}^{5} \mathrm{C} 34$ in mt-tRNA Met [35] (Figure 2). Hydroxymethylcytosine (hm ${ }^{5} \mathrm{C}$ ) was not observed as an intermediate in vitro. Although the presence of this modification cannot be ruled out, results seem to indicate that $\mathrm{hm}^{5} \mathrm{C}$ might not play an important role for mt-tRNA ${ }^{\text {Met }}$.

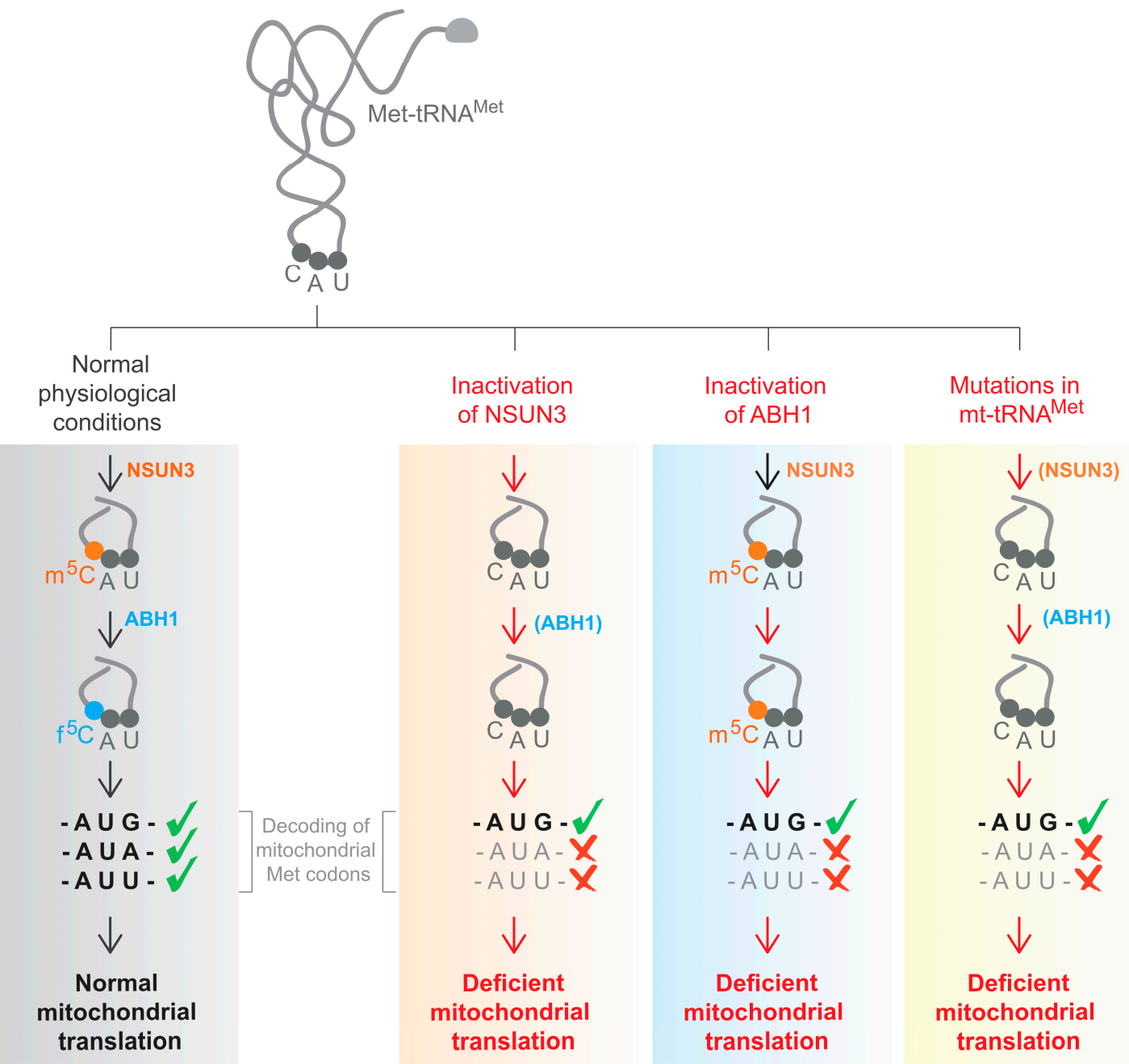

Figure 2. Formation of $\mathrm{f}^{5} \mathrm{C}$ by NSUN3 and $\mathrm{ABH} 1$ is crucial for codon recognition and normal mitochondrial translation (grey). Inactivation of NSUN3 (orange) or ABH1 (blue) abolishes the formation of $\mathrm{f}^{5} \mathrm{C} 34$ in mt-tRNA ${ }^{\text {Met }}$. Also, mutations in mitochondrial DNA that affect mt-tRNA ${ }^{\text {Met }}$ can lead to perturbations in the biogenesis of $\mathrm{f}^{5} \mathrm{C} 34$ (yellow). Proteins in brackets are available, but cannot perform their function because the correct substrate is missing. All three scenarios result in a failure of codon recognition, causing a mitochondrial translation deficiency.

Formylation of $\mathrm{m}^{5} \mathrm{C} 34$ of $\mathrm{mt}-\mathrm{tRNA} \mathrm{Met}^{\mathrm{Met}}$ is not the only function of $\mathrm{ABH} 1$ reported thus far. It also mediates the demethylation of $N^{1}$-methyladenosine in tRNAs and can modulate translation initiation and elongation by regulating the cellular levels of initiator tRNA ${ }^{\text {iMet }}$ in the cytoplasm [45]. ABH1 deficiency in mice results in an $80 \%$ reduction of the litter size due to embryonic lethality, with the surviving mice exhibiting neural development defects and sex-ratio distortion [46,47]. Notably, incubation of total $\mathrm{tRNA}$ with $\mathrm{ABH} 1$ led to a significant decrease in the $N^{1}$-methyladenosine $\left(\mathrm{m}^{1} \mathrm{~A}\right)$ level, but not levels of $\mathrm{m}^{5} \mathrm{C}$ [45]. Finally, ABH1 has also been shown to demethylate $N^{6}$-methyladenine, preferably on single stranded DNA, suggesting that the demethylation may be coupled with cellular transcription or replication [48]. 


\section{The Role $\mathrm{f}^{5} \mathrm{C} 34$ in $\mathrm{mt}^{-\mathrm{tRNA}} \mathrm{Aet}^{\mathrm{Met}}$}

As introduced earlier, owing to the specific features of the mammalian mitochondrial genetic code, the single tRNA ${ }^{\text {Met }}$ bearing a CAU anticodon recognizes the conventional methionine AUG codon as well as the AUA and AUU codons, conventionally coding for isoleucine.

Analysis of the chemically synthesised, $\mathrm{f}^{5} \mathrm{C} 34$-modified anticodon loop of human mitochondrial tRNA ${ }^{\text {Met }}$ showed that $\mathrm{f}^{5} \mathrm{C} 34$ contributes to the mt-tRNA's anticodon domain structure [49]. It was further demonstrated that $\mathrm{f}^{5} \mathrm{C} 34$ defined a reduced conformational space for the nucleoside due to a reduction in conformational dynamics of the anticodon bases [50]. The modification enhances the thermodynamic properties of the anticodon and its ability to bind the unconventional methionine codon AUA. Further analysis revealed that $\mathrm{f}^{5} \mathrm{C}$ is particularly important for AUA recognition at the ribosomal A-site and affects the kinetics of codon recognition at both the P- and A-sites [50]. Visualization of the codon-anticodon complex by X-ray crystallography showed that recognition of both $\mathrm{G}$ and $\mathrm{A}$ at the third position of the codon occurs in the canonical Watson-Crick geometry [51]. The $\mathrm{f}^{5} \mathrm{C}$ modification shifts the tautomeric equilibrium toward the rare imino-oxo tautomer of cytidine making base pairing with A possible. For more information on the structural insights into $\mathrm{f}^{5} \mathrm{C}$ in an RNA duplex, we refer to Wang et al. [52].

It is currently still undefined whether in vivo, the entire pool of mt-tRNA ${ }^{\text {Met }}$ has the $\mathrm{f}^{5} \mathrm{C} 34$ modification or whether differentially modified forms are used to modulate mitochondrial translation activity. In vitro codon recognition studies with chemically synthesised modified or unmodified

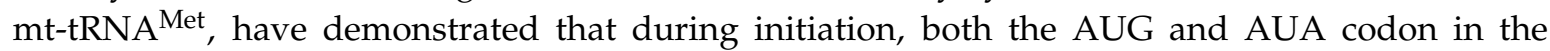
ribosomal P-site were preferentially recognized by $\mathrm{m}^{5} \mathrm{C} 34$-modified $\mathrm{mt}$-tRNA ${ }^{\text {Met }}$ [35]. Binding of $\mathrm{f}^{5} \mathrm{C}$ modified mt-tRNA ${ }^{\text {Met }}$ to these two codons was much lower and not significantly different compared to unmodified C34 mt-tRNA ${ }^{\text {Met }}$. Recognition of AUU was generally lower and not significantly different with respect to the mt-tRNA ${ }^{\text {Met }}$ modification. Notably, $\mathrm{m}^{5} \mathrm{C} 34$-modified mt-tRNA ${ }^{\text {Met }}$ was less efficient than other variants in AUG decoding during elongation. This suggests that $\mathrm{m}^{5} \mathrm{C} 34$ plays an actual role in mitochondrial translation, rather than just being an intermediate step in the $\mathrm{f}^{5} \mathrm{C} 34$ formation. The presence of substantial levels of $\mathrm{m}^{5} \mathrm{C} 34$ in mt-tRNA ${ }^{\text {Met }}$ was also detected by next generation sequencing methods derived from RNA bisulfite sequencing (BS). RNA BS is a well-established method to detect $\mathrm{m}^{5} \mathrm{C}$ and $\mathrm{hm}^{5} \mathrm{C}$. However, since bisulfite does convert $\mathrm{f}^{5} \mathrm{C}$, this approach cannot distinguish $\mathrm{f}^{5} \mathrm{C}$ from unmodified $\mathrm{C}$. Reduced bisulfite RNA sequencing (Red BS RNA-Seq) relies on the chemical reduction of $\mathrm{f}^{5} \mathrm{C}$ to $\mathrm{hm}^{5} \mathrm{C}$ by $\mathrm{NaBH}_{4}$, with the resulting $\mathrm{hm}^{5} \mathrm{C}$ being subsequently detected by RNA BS. Alternatively, 5-formylcytosine chemically assisted bisulfite RNA sequencing (fCAB RNA-Seq), is based upon $O$-ethylhydroxylamine protection of $\mathrm{f}^{5} \mathrm{C}$ from bisulfite conversion. These two approaches measured about $38 \% \mathrm{f}^{5} \mathrm{C}, 30 \% \mathrm{~m}^{5} \mathrm{C}$ (and $\mathrm{hm}^{5} \mathrm{C}$ ) and $32 \%$ unmodified mt-tRNA ${ }^{\text {Met }} \mathrm{C} 34$ [34]. It is possible, however, that these approaches overestimate the levels of unmodified $C$ due to an inefficient conversion/protection of $\mathrm{f}^{5} \mathrm{C}$. It should also be noted that this technique cannot distinguish mature mt-tRNA ${ }^{\text {Met }}$ from precursors.

The functional in vitro codon recognition studies and the results of the genome-wide detection of $\mathrm{f}^{5} \mathrm{C}$, however, are in disagreement with the mass spectrometry analysis shown by Nakano et al., 2016 [33], which suggests that the entire pool of mt-tRNA ${ }^{\text {Met }}$ has the $\mathrm{f}^{5} \mathrm{C} 34$ modification with undetectable amounts of $\mathrm{m}^{5} \mathrm{C} 34$ or unmodified $\mathrm{C} 34$. Therefore, further study will be required to establish whether alterations to the relative abundance of $\mathrm{m}^{5} \mathrm{C} 34$ and $\mathrm{f}^{5} \mathrm{C} 34$ modifications could participate in the regulation of mitochondrial translation.

There is currently no evidence that $\mathrm{f}^{5} \mathrm{C} 34$ is involved in mt-RNA ${ }^{\text {Met }}$ aminoacylation. Methionyl-tRNA synthetase (MetRS, MARS2) recognizes mt-tRNA ${ }^{\text {Met }}$ irrespective of the presence or absence of $\mathrm{f}^{5} \mathrm{C} 34$ without influencing the kinetics of aminoacylation [53]. This is supported by high-resolution Northern blot analysis on patient fibroblasts lacking a functional NSUN3 protein, and consequently lacking any C34 modification of mt-tRNA ${ }^{\text {Met }}$, showing no differences in aminoacylation levels compared to control fibroblasts [34]. 
Although current evidence supports a role for $\mathrm{f}^{5} \mathrm{C}$ in recognition of both the AUG and AUA codon in both the ribosomal A- and P-site, the exact function has yet to be elucidated. Nonetheless, severe impairment of de novo mitochondrial translation, with a consequent defect in oxygen consumption rate, was consistently observed upon inactivation of NSUN3 or ABH1 [33-35]. Therefore, the analysis of cells with the deficiency of NSUN3 or ABH1 has provided the first evidence for a physiological role of $\mathrm{f}^{5} \mathrm{C} 34$ in mt-tRNA ${ }^{\text {Met }}$ in living cells.

\section{The Role of $\mathrm{f}^{5} \mathrm{C} 34$ in mt-tRNA ${ }^{\text {Met }}$ in Human Disease}

Mitochondria contain multiple genomes per cell. As a result, mtDNA mutations may be present at any fraction, a condition referred to as heteroplasmy. The percentage of mutant mtDNA may vary among patients and among organs and tissues within the same individual. This partially explains the varied clinical phenotype seen in individuals with pathogenic mtDNA mutations. Different base substitutions in the same mt-tRNA or even the same point mutation can cause different clinical symptoms. Despite only accounting for approximately $5 \%$ of the total mtDNA sequence, pathogenic point mutations in mt-tRNAs are responsible for the majority of mitochondrial DNA diseases [54,55]. Some of these pathogenetic alterations have been shown to interfere with post-transcriptional mt-tRNA modifications $[18,56,57]$. The effects of primary mt-tRNA mutations on maturation and post-transcriptional modifications are discussed elsewhere [1,58,59].

Eight pathogenic mutations in mt-tRNA ${ }^{\text {Met }}$ have been reported to date with a broad range of symptoms (MITOMAP) [60]. While m.4335A $>\mathrm{G}$ is associated with maternally inherited hypertension or Leber's hereditary optic neuropathy [61,62], m.T4409T > C and m.G4450G > A cause myopathy $[63,64]$ and $\mathrm{m} .4437 \mathrm{C}>\mathrm{T}$ is associated with hypotonia, seizures, muscle weakness, lactic acidosis and hearing loss [65]. Differentially affected levels of C34 modifications in mt-tRNA ${ }^{\text {Met }}$ could provide a possible explanation for this wide clinical phenotypic variation in the symptoms associated with mutations in the same mt-tRNA. Two out of eight mutations (m.A4435A $>$ G and m.C4437C > T) inhibited NSUN3-mediated $\mathrm{m}^{5} \mathrm{C}$ formation in vitro, suggesting that in these mutations, the molecular pathogenesis can be at least partially attributed to the absence of $\mathrm{f}^{5} \mathrm{C}$ in mt-tRNA ${ }^{\text {Met }}$ [33]. Both these mutations are localized in the anticodon arm of the mt-tRNA ${ }^{\text {Met }}$. These results are in line with another study that shows that NSUN3 requires a stable anticodon stem loop for methylation of cytosine 34 [35].

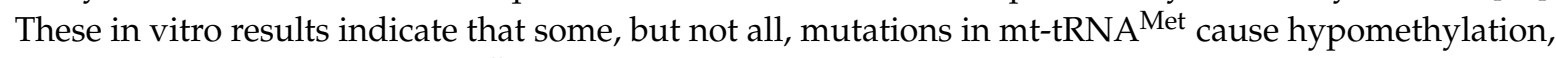
resulting in a reduced level of $\mathrm{f}^{5} \mathrm{C}$.

The importance of this post-transcriptional modification of C34 of mt-tRNA ${ }^{\text {Met }}$ is further supported by our recent study that describes a patient who has no detectable levels of $\mathrm{m}^{5} \mathrm{C} 34$ or $\mathrm{f}^{5} \mathrm{C} 34$. Whole-exome sequencing had identified compound heterozygous predicted loss-of-function variants in the NSUN3 gene and no functional NSUN3 protein was detected. This patient developed mitochondrial disease symptoms at the age of three months. Symptoms were combined developmental disability, microcephaly, failure to thrive, recurrent increased lactate levels in plasma, muscular weakness, external ophthalmoplegia and convergence nystagmus [34]. Taken together, these data show that detailed understanding of the basic mechanistic aspects of mt-tRNA modifications might be helpful for explaining the different clinical presentations of mitochondrial diseases related to genetic defects in the molecular biology of mt-tRNA.

\section{Concluding Remarks}

Methylation of C34 in mt-tRNA ${ }^{\text {Met }}$ by NSUN3, followed by further oxidation to $\mathrm{f}^{5} \mathrm{C} 34$ by ABH1, is essential for mitochondrial translation and mitochondrial function. However, it is still unclear whether $\mathrm{m}^{5} \mathrm{C} 34$ in mt-tRNA ${ }^{\text {Met }}$ is a transient intermediate or whether this modification plays an actual role in mitochondrial translation regulation. Furthermore, it would also be interesting to check for additional functions of $\mathrm{ABH} 1$ in mitochondria that could contribute to tuning translation initiation and elongation. To summarize, although current evidence supports an important role for $\mathrm{f}^{5} \mathrm{C} 34$ and 
possibly $\mathrm{m}^{5} \mathrm{C} 34$ in codon recognition in both initiation and elongation, the exact in vivo role has yet to be elucidated.

Acknowledgments: Medical Research Council, UK is gratefully acknowledged for generous support of this work. Author Contributions: All authors contributed to the writing and design of the manuscript.

Conflicts of Interest: The authors declare no conflict of interest.

\section{References}

1. Van Haute, L.; Pearce, S.F.; Powell, C.A.; D'Souza, A.R.; Nicholls, T.J.; Minczuk, M. Mitochondrial transcript maturation and its disorders. J. Inherit. Metab. Dis. 2015, 38, 655-680. [CrossRef] [PubMed]

2. Rorbach, J.; Minczuk, M. The post-transcriptional life of mammalian mitochondrial RNA. Biochem. J. 2012, 444, 357-373. [CrossRef] [PubMed]

3. Hallberg, B.M.; Larsson, N.G. Making proteins in the powerhouse. Cell Metab. 2014, 20, 226-240. [CrossRef] [PubMed]

4. Boczonadi, V.; Horvath, R. Mitochondria: Impaired mitochondrial translation in human disease. Int. J. Biochem. Cell Biol. 2014, 48, 77-84. [CrossRef] [PubMed]

5. Nicholls, T.J.; Rorbach, J.; Minczuk, M. Mitochondria: Mitochondrial RNA metabolism and human disease. Int. J. Biochem. Cell Biol. 2013, 45, 845-849. [CrossRef] [PubMed]

6. Gustafsson, C.M.; Falkenberg, M.; Larsson, N.G. Maintenance and expression of mammalian mitochondrial DNA. Annu. Rev. Biochem. 2016, 85, 133-160. [CrossRef] [PubMed]

7. Ott, M.; Amunts, A.; Brown, A. Organization and regulation of mitochondrial protein synthesis. Annu. Rev. Biochem. 2016, 85, 77-101. [CrossRef] [PubMed]

8. Rogalski, M.; Karcher, D.; Bock, R. Superwobbling facilitates translation with reduced tRNA sets. Nat. Struct. Mol. Biol. 2008, 15, 192-198. [CrossRef] [PubMed]

9. Young, I.G.; Anderson, S. The genetic code in bovine mitochondria: Sequence of genes for the cytochrome oxidase subunit II and two tRNAs. Gene 1980, 12, 257-265. [CrossRef]

10. Temperley, R.; Richter, R.; Dennerlein, S.; Lightowlers, R.N.; Chrzanowska-Lightowlers, Z.M. Hungry codons promote frameshifting in human mitochondrial ribosomes. Science 2010, 327, 301. [CrossRef] [PubMed]

11. Akabane, S.; Ueda, T.; Nierhaus, K.H.; Takeuchi, N. Ribosome Rescue and Translation Termination at Non-standard Stop Codons by ICT1 in Mammalian Mitochondria. PLoS Genet. 2014, 10, e1004616. [CrossRef] [PubMed]

12. Takeuchi, N.; Nierhaus, K.H. Response to the Formal Letter of Z. Chrzanowska-Lightowlers and R. N. Lightowlers Regarding Our Article “Ribosome Rescue and Translation Termination at Non-Standard Stop Codons by ICT1 in Mammalian Mitochondria". PLoS Genet. 2015, 11, e1005218. [CrossRef] [PubMed]

13. Chrzanowska-Lightowlers, Z.M.; Lightowlers, R.N. Response to "Ribosome Rescue and Translation Termination at Non-sSandard Stop Codons byICT1 in Mammalian Mitochondria". PLoS Genet. 2015, 11, e1005227. [CrossRef] [PubMed]

14. Takemoto, C.; Koike, T.; Yokogawa, T.; Benkowski, L.; Spremulli, L.L.; Ueda, T.A.; Nishikawa, K.; Watanabe, K. The ability of bovine mitochondrial transfer RNAMet to decode AUG and AUA codons. Biochimie 1995, 77, 104-108. [CrossRef]

15. Suzuki, T.; Nagao, A.; Suzuki, T. Human mitochondrial tRNAs: Biogenesis, function, structural aspects, and diseases. Annu. Rev. Genet. 2011, 45, 299-329. [CrossRef] [PubMed]

16. Suzuki, T.; Suzuki, T. A complete landscape of post-transcriptional modifications in mammalian mitochondrial tRNAs. Nucleic Acids Res. 2014, 42, 7346-7357. [CrossRef] [PubMed]

17. Powell, C.A.; Nicholls, T.J.; Minczuk, M. Nuclear-encoded factors involved in post-transcriptional processing and modification of mitochondrial tRNAs in human disease. Front. Genet. 2015, 6, 79. [CrossRef] [PubMed]

18. Yarham, J.W.; Lamichhane, T.N.; Pyle, A.; Mattijssen, S.; Baruffini, E.; Bruni, F.; Donnini, C.; Vassilev, A.; He, L.; Blakely, E.L.; et al. Defective i ${ }^{6}$ A37 Modification of Mitochondrial and Cytosolic tRNAs Results from Pathogenic Mutations in TRIT1 and Its Substrate tRNA. PLoS Genet. 2014, 10, e1004424. [CrossRef] [PubMed]

19. Ghezzi, D.; Baruffini, E.; Haack, T.B.; Invernizzi, F.; Melchionda, L.; Dallabona, C.; Strom, T.M.; Parini, R.; Burlina, A.B.; Meitinger, T.; et al. Mutations of the Mitochondrial-tRNA Modifier MTO1 Cause Hypertrophic Cardiomyopathy and Lactic Acidosis. Am. J. Hum. Genet. 2012, 90, 1079-1087. [CrossRef] [PubMed] 
20. Powell, C.A.; Kopajtich, R.; D’Souza, A.R.; Rorbach, J.; Kremer, L.S.; Husain, R.A.; Dallabona, C.; Donnini, C.; Alston, C.L.; Griffin, H.; et al. TRMT5 Mutations Cause a Defect in Post-transcriptional Modification of Mitochondrial tRNA Associated with Multiple Respiratory-Chain Deficiencies. Am. J. Hum. Genet. 2015, 97, 319-328. [CrossRef] [PubMed]

21. Kopajtich, R.; Nicholls, T.J.; Rorbach, J.; Metodiev, M.D.; Freisinger, P.; Mandel, H.; Vanlander, A.; Ghezzi, D.; Carrozzo, R.; Taylor, R.W.; et al. Mutations in GTPBP3 cause a mitochondrial translation defect associated with hypertrophic cardiomyopathy, lactic acidosis, and encephalopathy. Am. J. Hum. Genet. 2014, 95, 708-720. [CrossRef] [PubMed]

22. Umeda, N.; Suzuki, T.; Yukawa, M.; Ohya, Y.; Shindo, H.; Watanabe, K. Mitochondria-specific RNA-modifying enzymes responsible for the biosynthesis of the wobble base in mitochondrial tRNAs. Implications for the molecular pathogenesis of human mitochondrial diseases. J. Biol. Chem. 2005, 280, 1613-1624. [CrossRef] [PubMed]

23. Bykhovskaya, Y.; Casas, K.; Mengesha, E.; Inbal, A.; Fischel-Ghodsian, N. Missense mutation in pseudouridine synthase 1 (PUS1) causes mitochondrial myopathy and sideroblastic anemia (MLASA). Am. J. Hum. Genet. 2004, 74, 1303-1308. [CrossRef] [PubMed]

24. Fernandez-Vizarra, E.; Berardinelli, A.; Valente, L.; Tiranti, V.; Zeviani, M. Nonsense mutation in pseudouridylate synthase 1 (PUS1) in two brothers affected by myopathy, lactic acidosis and sideroblastic anaemia (MLASA). J. Med. Genet. 2007, 44, 173-180. [CrossRef] [PubMed]

25. Baruffini, E.; Dallabona, C.; Invernizzi, F.; Yarham, J.W.; Melchionda, L.; Blakely, E.L.; Lamantea, E.; Donnini, C.; Santra, S.; Vijayaraghavan, S.; et al. MTO1 mutations are associated with hypertrophic cardiomyopathy and lactic acidosis and cause respiratory chain deficiency in humans and yeast. Hum. Mutat. 2013, 34, 1501-1509. [CrossRef] [PubMed]

26. Najmabadi, H.; Hu, H.; Garshasbi, M.; Zemojtel, T.; Abedini, S.S.; Chen, W.; Hosseini, M.; Behjati, F.; Haas, S.; Jamali, P.; et al. Deep sequencing reveals 50 novel genes for recessive cognitive disorders. Nature 2011, 478, 57-63. [CrossRef] [PubMed]

27. Zeharia, A.; Shaag, A.; Pappo, O.; Mager-Heckel, A.M.; Saada, A.; Beinat, M.; Karicheva, O.; Mandel, H.; Ofek, N.; Segel, R.; et al. Acute Infantile Liver Failure Due to Mutations in the TRMU Gene. Am. J. Hum. Genet. 2009, 85, 401-407. [CrossRef] [PubMed]

28. Moriya, J.; Yokogawa, T.; Wakita, K.; Ueda, T.; Nishikawa, K.; Crain, P.F.; Hashizume, T.; Pomerantz, S.C.; McCloskey, J.A.; Kawai, G.; et al. A novel modified nucleoside found at the first position of the anticodon of methionine tRNA from bovine liver mitochondria. Biochemistry 1994, 33, 2234-2239. [CrossRef] [PubMed]

29. Watanabe, Y.; Tsurui, H.; Ueda, T.; Furushima, R.; Takamiya, S.; Kita, K.; Nishikawa, K.; Watanabe, K. Primary and higher order structures of nematode (Ascaris suum) mitochondrial tRNAs lacking either the T or D stem. J. Biol. Chem. 1994, 269, 22902-22906. [PubMed]

30. Tomita, K.; Ueda, T.; Watanabe, K. 5-formylcytidine (f5C) found at the wobble position of the anticodon of squid mitochondrial tRNA(Met)CAU. Nucleic Acids Symp. Ser. 1997, 197-198.

31. Tomita, K.; Ueda, T.; Ishiwa, S.; Crain, P.F.; McCloskey, J.A.; Watanabe, K. Codon reading patterns in Drosophila melanogaster mitochondria based on their tRNA sequences: A unique wobble rule in animal mitochondria. Nucleic Acids Res. 1999, 27, 4291-4297. [CrossRef] [PubMed]

32. Takemoto, C.; Ueda, T.; Miura, K.; Watanabe, K. Nucleotide sequences of animal mitochondrial tRNAs(Met) possibly recognizing both AUG and AUA codons. Nucleic Acids Symp. Ser. 1999, 42, 77-78. [CrossRef]

33. Nakano, S.; Suzuki, T.; Kawarada, L.; Iwata, H.; Asano, K.; Suzuki, T. NSUN3 methylase initiates 5-formylcytidine biogenesis in human mitochondrial tRNA(Met). Nat. Chem. Biol. 2016, 12, 546-551. [CrossRef] [PubMed]

34. Van Haute, L.; Dietmann, S.; Kremer, L.; Hussain, S.; Pearce, S.F.; Powell, C.A.; Rorbach, J.; Lantaff, R.; Blanco, S.; Sauer, S.; et al. Deficient methylation and formylation of mt-tRNA ${ }^{\text {Met }}$ wobble cytosine in a patient carrying mutations in NSUN3. Nat. Commun. 2016, 7, 12039. [CrossRef] [PubMed]

35. Haag, S.; Sloan, K.E.; Ranjan, N.; Warda, A.S.; Kretschmer, J.; Blessing, C.; Hubner, B.; Seikowski, J.; Dennerlein, S.; Rehling, P.; et al. NSUN3 and ABH1 modify the wobble position of mt-tRNA ${ }^{\text {Met }}$ to expand codon recognition in mitochondrial translation. EMBO J. 2016, 35, 2104-2119. [CrossRef] [PubMed]

36. Bachman, M.; Uribe-Lewis, S.; Yang, X.; Burgess, H.E.; Iurlaro, M.; Reik, W.; Murrell, A.; Balasubramanian, S. 5-formylcytosine can be a stable DNA modification in mammals. Nat. Chem. Biol. 2015, 11, 555-557. [CrossRef] [PubMed] 
37. Brzezicha, B.; Schmidt, M.; Makalowska, I.; Jarmolowski, A.; Pienkowska, J.; Szweykowska-Kulinska, Z. Identification of human tRNA:m5C methyltransferase catalysing intron-dependent $\mathrm{m} 5 \mathrm{C}$ formation in the first position of the anticodon of the pre-tRNA Leu (CAA). Nucleic Acids Res. 2006, 34, 6034-6043. [CrossRef] [PubMed]

38. Haag, S.; Warda, A.S.; Kretschmer, J.; Gunnigmann, M.A.; Hobartner, C.; Bohnsack, M.T. NSUN6 is a human RNA methyltransferase that catalyzes formation of m5C72 in specific tRNAs. RNA 2015, 21, 1532-1543. [CrossRef] [PubMed]

39. Sloan, K.E.; Leisegang, M.S.; Doebele, C.; Ramirez, A.S.; Simm, S.; Safferthal, C.; Kretschmer, J.; Schorge, T.; Markoutsa, S.; Haag, S.; et al. The association of late-acting snoRNPs with human pre-ribosomal complexes requires the RNA helicaseDDX21. Nucleic Acids Res. 2015, 43, 553-564. [CrossRef] [PubMed]

40. Schosserer, M.; Minois, N.; Angerer, T.B.; Amring, M.; Dellago, H.; Harreither, E.; Calle-Perez, A.; Pircher, A.; Gerstl, M.P.; Pfeifenberger, S.; et al. Methylation of ribosomal RNA by NSUN5 is a conserved mechanism modulating organismal lifespan. Nat. Commun. 2015, 6, 6158. [CrossRef] [PubMed]

41. Camara, Y.; Asin-Cayuela, J.; Park, C.B.; Metodiev, M.D.; Shi, Y.; Ruzzenente, B.; Kukat, C.; Habermann, B.; Wibom, R.; Hultenby, K.; et al. MTERF4 regulates translation by targeting the methyltransferase NSUN4 to the mammalian mitochondrial ribosome. Cell Metab. 2011, 13, 527-539. [CrossRef] [PubMed]

42. Metodiev, M.D.; Spahr, H.; Loguercio Polosa, P.; Meharg, C.; Becker, C.; Altmueller, J.; Habermann, B.; Larsson, N.G.; Ruzzenente, B. NSUN4 is a Dual Function Mitochondrial Protein Required for Both Methylation of 12S rRNA and Coordination of Mitoribosomal Assembly. PLoS Genet. 2014, 10, e1004110. [CrossRef] [PubMed]

43. Rhee, H.W.; Zou, P.; Udeshi, N.D.; Martell, J.D.; Mootha, V.K.; Carr, S.A.; Ting, A.Y. Proteomic mapping of mitochondria in living cells via spatially restricted enzymatic tagging. Science 2013, 339, 1328-1331. [CrossRef] [PubMed]

44. Fedeles, B.I.; Singh, V.; Delaney, J.C.; Li, D.; Essigmann, J.M. The AlkB family of Fe(II)/ $\alpha$-Ketoglutaratedependent Dioxygenases: Repairing nucleic acid alkylation damage and beyond. J. Biol. Chem. 2015, 290, 20734-20742. [CrossRef] [PubMed]

45. Liu, F.; Clark, W.; Luo, G.; Wang, X.; Fu, Y.; Wei, J.; Wang, X.; Hao, Z.; Dai, Q.; Zheng, G.; et al. ALKBH1-Mediated tRNA Demethylation Regulates Translation. Cell 2016, 167, 816-828. [CrossRef] [PubMed]

46. Nordstrand, L.M.; Svard, J.; Larsen, E.; Nilsen, A.; Ougland, R.; Furu, K.; Lien, G.F.; Rognes, T.; Namekawa, S.H.; Lee, J.T.; et al. Mice lacking ALKBH1 display sex-ratio distortion and unilateral eye defects. PLoS ONE 2010, 5, e13827. [CrossRef] [PubMed]

47. Ougland, R.; Lando, D.; Jonson, I.; Dahl, J.A.; Moen, M.N.; Nordstrand, L.M.; Rognes, T.; Lee, J.T.; Klungland, A.; Kouzarides, T.; et al. ALKBH1 is a histone H2A dioxygenase involved in neural differentiation. Stem Cells 2012, 30, 2672-2682. [CrossRef] [PubMed]

48. Wu, T.P.; Wang, T.; Seetin, M.G.; Lai, Y.; Zhu, S.; Lin, K.; Liu, Y.; Byrum, S.D.; Mackintosh, S.G.; Zhong, M.; et al. DNA methylation on N(6)-adenine in mammalian embryonic stem cells. Nature 2016, 532, 329-333. [CrossRef] [PubMed]

49. Lusic, H.; Gustilo, E.M.; Vendeix, F.A.; Kaiser, R.; Delaney, M.O.; Graham, W.D.; Moye, V.A.; Cantara, W.A.; Agris, P.F.; Deiters, A. Synthesis and investigation of the 5-formylcytidine modified, anticodon stem and loop of the human mitochondrial tRNA ${ }^{\text {Met }}$. Nucleic Acids Res. 2008, 36, 6548-6557. [CrossRef] [PubMed]

50. Bilbille, Y.; Gustilo, E.M.; Harris, K.A.; Jones, C.N.; Lusic, H.; Kaiser, R.J.; Delaney, M.O.; Spremulli, L.L.;

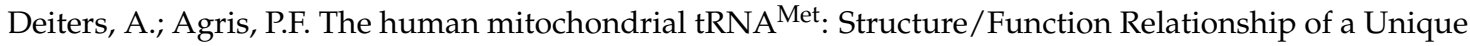
Modification in the Decoding of Unconventional Codons. J. Mol. Biol. 2011, 406, 257-274. [CrossRef] [PubMed]

51. Cantara, W.A.; Murphy, F.V.T.; Demirci, H.; Agris, P.F. Expanded use of sense codons is regulated by modified cytidines in tRNA. Proc. Natl. Acad. Sci. USA 2013, 110, 10964-10969. [CrossRef] [PubMed]

52. Wang, R.; Luo, Z.; He, K.; Delaney, M.O.; Chen, D.; Sheng, J. Base pairing and structural insights into the 5-formylcytosine in RNA duplex. Nucleic Acids Res. 2016, 44, 4968-4977. [CrossRef] [PubMed]

53. Spencer, A.C.; Heck, A.; Takeuchi, N.; Watanabe, K.; Spremulli, L.L. Characterization of the human mitochondrial methionyl-tRNA synthetase. Biochemistry 2004, 43, 9743-9754. [CrossRef] [PubMed]

54. Anderson, S.; Bankier, A.T.; Barrell, B.G.; de Bruijn, M.H.; Coulson, A.R.; Drouin, J.; Eperon, I.C.; Nierlich, D.P.; Roe, B.A.; Sanger, F.; et al. Sequence and organization of the human mitochondrial genome. Nature 1981, 290, 457-465. [CrossRef] [PubMed] 
55. Yarham, J.W.; Elson, J.L.; Blakely, E.L.; McFarland, R.; Taylor, R.W. Mitochondrial tRNA mutations and disease. Wiley Interdiscip. Rev. RNA 2010, 1, 304-324. [CrossRef] [PubMed]

56. Brule, H.; Holmes, W.M.; Keith, G.; Giege, R.; Florentz, C. Effect of a mutation in the anticodon of human mitochondrial tRNAPro on its post-transcriptional modification pattern. Nucleic Acids Res. 1998, 26, 537-543. [CrossRef] [PubMed]

57. Yasukawa, T.; Kirino, Y.; Ishii, N.; Holt, I.J.; Jacobs, H.T.; Makifuchi, T.; Fukuhara, N.; Ohta, S.; Suzuki, T.; Watanabe, K. Wobble modification deficiency in mutant tRNAs in patients with mitochondrial diseases. FEBS Lett. 2005, 579, 2948-2952. [CrossRef] [PubMed]

58. Kirino, Y.; Suzuki, T. Human mitochondrial diseases associated with tRNA wobble modification deficiency. RNA Biol. 2005, 2, 41-44. [CrossRef] [PubMed]

59. Levinger, L.; Morl, M.; Florentz, C. Mitochondrial tRNA 3' end metabolism and human disease. Nucleic Acids Res. 2004, 32, 5430-5441. [CrossRef] [PubMed]

60. Lott, M.T.; Leipzig, J.N.; Derbeneva, O.; Xie, H.M.; Chalkia, D.; Sarmady, M.; Procaccio, V.; Wallace, D.C. mtDNA Variation and Analysis Using MITOMAP and MITOMASTER. Curr. Protoc. Bioinform. 2013, 44, 1-23. [PubMed]

61. Lu, Z.; Chen, H.; Meng, Y.; Wang, Y.; Xue, L.; Zhi, S.; Qiu, Q.; Yang, L.; Mo, J.Q.; Guan, M.X. The tRNA $^{\text {Met }} 4435 \mathrm{~A}>\mathrm{G}$ mutation in the mitochondrial haplogroup G2a1 is responsible for maternally inherited hypertension in a Chinese pedigree. Eur. J. Hum. Genet. 2011, 19, 1181-1186. [CrossRef] [PubMed]

62. Qu, J.; Li, R.; Zhou, X.; Tong, Y.; Lu, F.; Qian, Y.; Hu, Y.; Mo, J.Q.; West, C.E.; Guan, M.X. The Novel A4435G Mutation in the Mitochondrial tRNA ${ }^{\text {Met }}$ May Modulate the Phenotypic Expression of the LHON-Associated ND4 G11778A Mutation. Investig. Ophthalmol. Vis. Sci. 2006, 47, 475-483. [CrossRef] [PubMed]

63. Vissing, J.; Salamon, M.B.; Arlien-Soborg, P.; Norby, S.; Manta, P.; DiMauro, S.; Schmalbruch, H. A new mitochondrial $\mathrm{tRNA}^{\mathrm{Met}}$ gene mutation in a patient with dystrophic muscle and exercise intolerance. Neurology 1998, 50, 1875-1878. [CrossRef] [PubMed]

64. Sternberg, D.; Danan, C.; Lombes, A.; Laforet, P.; Girodon, E.; Goossens, M.; Amselem, S. Exhaustive scanning approach to screen all the mitochondrial tRNA genes for mutations and its application to the investigation of 35 independent patients with mitochondrial disorders. Hum. Mol. Genet. 1998, 7, $33-42$. [CrossRef] [PubMed]

65. Tang, S.; Wang, J.; Zhang, V.W.; Li, F.Y.; Landsverk, M.; Cui, H.; Truong, C.K.; Wang, G.; Chen, L.C.; Graham, B.; et al. Transition to next generation analysis of the whole mitochondrial genome: A summary of molecular defects. Hum. Mutat. 2013, 34, 882-893. [CrossRef] [PubMed] 